\title{
Differences between Women and Men in terms of Safety Measures to Prevent COVID-19 Pandemic in the Hotel Sector
}

\author{
Alexandra Lenis Escobar ${ }^{1}$, Ramón Rueda López ${ }^{2 *}$, Antonio Menor Campos ${ }^{3}$ and Teresa \\ López-Felipe ${ }^{2}$ \\ 1 Researcher at “Grupo de Investigación SEJ-588 Economía del Turismo, de la Cultura y del Deporte. \\ University of Cordoba (UCO)”, 14071, Córdoba, Spain; r52leesa@uco.es \\ 2 Department of Statistic, Econometrics, Operational Research, Business Organization and Applied \\ Economics, University of Cordoba, 14071, Córdoba, Spain; ramon.rueda@uco.es (R.R.L.); mtlopez@uco.es \\ (T.L-F.) \\ 3 Department of Agrarian Economy, Finance and Accounting. University of Cordoba (UCO), 14071, Córdoba, \\ Spain; es1mecaa@uco.es \\ * Correspondence: ramon.rueda@uco.es
}

Received: date; Accepted: date; Published: date

\begin{abstract}
The tourism sector in general and the hotelier in particular face the challenge of managing appropriate measures to deal with the covid-19 pandemic. In this sense it is useful to know what the measures are most demanded by the clientele. This research, by analyzing the variance (ANOVA) of a factor concluded that women are more demanding than men in terms of the level of demand in relation to the measures to be taken in hotels. This, as a practical application, allows to know more accurately the expectations, demands and demands of the client segmented by sex, in order to satisfy and improve the tourist experiences.
\end{abstract}

Keywords: Covid-19, tourism, hotel sector, security measures, sex differences, ANOVA

\section{Introduction}

On March 11, 2020, the World Health Organization (WHO) declared a global pandemic caused by the SARS-CoV-2 coronavirus strain [1]. This pandemic has spread globally in a few months, affecting economic and social aspects around the world. Travel bans and social estrangement are recurrent public health guidelines in pandemic containment and have had a major impact in industries with high levels of human interaction or "high contact" [2], such as hotels or other tourist activities, hard hit in this period [3]. However, the pandemic of the COVID-19 is not the first health crisis affecting travel in particular and tourism in general. In recent decades, other viral epidemics such as SARS (also known as SARS-CoV-1), MERS, swine flu, Ebola, Zika or yellow fever have also threatened public health around the world [4]. Unlike health problems such as the 2003 SARS outbreak or the Ebola crisis of natural disasters [5-9] or of social revolts such as the Arab Spring [10], the COVID-19 pandemic is a reality. However, according to Lori Pennington-Gray, director of the Tourism Crisis Management Initiative, it is the first time that a health crisis (or of any other type) has become a global crisis and is affecting all countries of the world and all facets of tourism activity [11].

Paradoxically, tourism activities, and especially travel, have become a vehicle for the diseases likely to become pandemics and, therefore, as the sector most affected by actions designed by the public health authorities for the mitigation of the pandemic [9]. The connection between tourism services and the risk of health disasters has forced governments to restrict, or even prohibit, travel as a measure of managing the risks posed by the transmission of the virus [1,9].

Air transport is currently the main means of pandemic spread [12], hence the measures taken to minimize SARS transmission between March and May 2003 will focus on reducing passenger 
numbers at the major airports concerned. This reduction was between $57 \%$ and $77 \%$. Similarly, it has happened in other health crises. Thus, in 2009 there was a reduction in passenger volume of between $4.12 \%$ and $7.88 \%$ due to swine flu. However, as a differentiating element, in the case of avian influenza, in 2006, passenger volume in affected areas increased by $9.04 \%$ to $16 \%$. In these three previous pandemics, measures such as temperature-taking of travelers were adopted at airports, containing travelers with symptoms. In fact, the responses given by countries in the current pandemic have followed protocols similar to the authors $[13,14]$. However, there are aspects that differentiate the current pandemic from the previous ones, in terms of its effects, the scope and effectiveness of the measures taken to contain them, such as, for example, the life cycle of pathogens caused by quarantine situations. According to the experts, the lack of preparation of the tourism industry in the current situation would be explained by the differences in the COVID-19 pandemic in relation to those mentioned above since these did not have a significant impact on the decline in international travel [9]. On the other hand, the incubation period of the other pandemics was shorter and more noticeable compared to COVID-19's sometimes undetectable. That characteristic has facilitated its spread via travelers [15]. The adjustment of the expectations placed by the World Tourism Organization (UNWTO) from predicting on 6 March 2020 a 2\%-3\% reduction in international travel is significant, compared to the 2019 figures, to a $20 \%-30 \%$ reduction announced by 26 March 2020 [9], which in subsequent months was increasing.

The objective of this research is to present the results of a study carried out in Spain to know the perceptions and opinions of travelers in the situation in which it will be found in tourist destinations that are marked by this pandemic.

In this regard, this research will address gender targeting, which will make it possible to verify the differences that may exist in terms of women and men. This segmentation will allow to better understand the needs, demands and expectations of both population groups. On the other hand, it may allow the tourism sector to obtain a return from women's opinions regarding the risks perceived during travel [16].

\section{Theoretical Background.}

\subsection{Impact and consequences.}

The impact of COVID-19 and its consequences on tourism will depend on factors marked by uncertainty, which can be grouped into three categories: first, the duration of the crisis (pandemic control, travel restrictions, reactivation of transport, control of successive waves of COVID-19, etc.); second, the support policies that governments implement (who the beneficiaries will be, how effective these policies will be, etc.); and third, the kind of tourist behavior that will arise (if consumers decrease or intensify their desire to travel; the role that confidence among tourists will play in nations or areas as a tourist destination, how health and safety are perceived, etc.). These three categories of external factors are complemented by situational factors in each of the destinations such as dependence on tourism, proper governance of the destination at different levels or the willingness to adapt to a different tourist behavior [17].

There are also voices that say nothing will ever be the same again in tourist activity and the high likelihood that the socio-economic changes produced by this pandemic will have a very significant impact on tourism in aspects such as mobility, patterns of socialization and consumption, or the relationship between leisure and work [18]. UNWTO estimated a decrease of between $20 \%$ and $30 \%$ in international tourist arrivals and corresponding economic income in 2020 compared to 2019. However, UNWTO recognizes that such estimates should be treated with considerable caution, given the magnitude, volatility and completely different profile of this health crisis compared to previous pandemics [19].

\subsection{Possibilities and challenges.}


The pandemic of the COVID-19 is causing a huge problem for tourism activity in all countries and it is unknown how the tourism sector will develop afterwards, in a period of economic and social crisis. Therefore, the key question, and which is the objective of this research, is what tourists will do when they can travel again, and for this question there are several answers that are related to the transformation that the COVID-19 pandemic will provoke in tourist activity.

From the scientific research perspective, the transformative potential of the pandemic towards sustainability is emphasized, reconsidering a global tourism system more aligned with the United Nations Sustainable Development Goals $[8,9,20]$. Thus, the importance of a tourist model aligned with the ODS should be focused on sustainability and people as a question of coherence and justice; with a technical and political basis in line with the achievement of the SDGs and to mark the roadmap to the new future of tourism [21]. The post covid-19 tourism model must have a developed learning capacity, be able to anticipate future crises, new priorities and needs of the population and tourists [22].

Sustainability refers to how specific models of ecological partner systems respond to disturbances [23]. It tries to respond to how tourism can adapt to the social, political and economic change that is causing this pandemic [24]. UNWTO's approach [19] is broader and concerns the SDGs and resilience along with institutional strengthening to mitigate the impact of the health crisis and accelerate economic and social recovery. The current situation has reopened the debate on the current unsustainability of the tourism sector and the risks posed by this tourism model in relation to both climate change and global health emergencies [2].

Criticisms from scientific researchers in recent years point to the need to modify this tourism model and bring it closer to resilience [24,25], considering, in short, profound structural changes in tourist activity. Berbés-Blázquez [26] have applied to the general tourist context the principles of resilience set out by Biggs et al. [27]. These principles can be summarized in the following:

(a) Diversity and redundancy: different types of attractions, different groups of objectives to combat vulnerability and overcrowding, organization of events, etc.;

(b) Connectivity: the links of a tourism system, which requires networks at various levels from aviation for international tourism to land transport for local tourism;

(c) Management of slow variables and feedback: slow variables report on the dynamics of a system, such as the diverse and changing preferences of tourists, while fast ones do so about the flow of tourists

(d) Experimentation and learning: development of new forms of tourism and innovative offers, tourism destination management teams to promote research and learning of tourist patterns;

(e) Central participation and governance: meeting of the various stakeholders, citizens and experts, to improve decision-making, and the independence of units acting with vertical and horizontal links.

The need to curb uncontrolled and therefore unsustainable growth of international tourist travel and to opt for decline strategies, especially in saturated destinations suffering from "overtourism" $[28,29]$ contrasts with the opposite situation that is being experienced today as is the absence of tourism. Despite the uncertainty, it is expected to strengthen proximity tourism in response to the health crisis [30], which involves strengthening proximity travel [31]; Jeuring and Haartsen [32]. The aftermath of COVID-19 in the tourist activity anticipates the emergence of new tourist consumption habits based on greater social and environmental awareness [6,33], which will show consumer concern about sustainability and social problems, both nationally and internationally [33-37]. Consequently, post-covid 19 tourists will choose to travel to destinations closer to their place of residence.

In the context of insecurity and uncertainty, nearby destinations could be considered "less risky" by many potential tourists who, having been remarkably affected by the social and economic crisis arising from the health crisis, have seen their purchasing power reduced. Added to this are restrictions on international (long-distance) travel, at least for a while, to help reduce air pollution, which would undoubtedly be in line with the promotion of more sustainable tourism and the development of the concept of decline. In this regard, greater adaptation to future pandemics of 
those companies that adapt to the expected change in the consumer, which will include a greater demand for sustainable tourism is expected [33]. This implies that tourism companies must be strongly rooted in the destination, that have been loyal to the principles of sustainable tourism, that offer ecotourism products or based on the local natural and cultural heritage, that provide high quality experiences for tourists and that achieve an added value for the destiny and, logically, for the local community itself.

As a result, a paradigm shift for post-COVID-19 tourism will replace the market share approach with one based on value sharing and where the marketing of tourism companies has to be oriented to listen to what they want and what people are passionate about in order to share and satisfy those desires [38]. This transition advocates transformative tourism [39-46] based on regenerative growth [47] and which can be summarized in the following points: first, a greater commitment between the guest and the host; second, a commitment to the administration of the natural resources on which tourism depends; third, an approach between what the community wants to share and what the visitor values; and fourth, greater participation of the local community leading to greater creativity, collaboration and resilience of the destinations themselves.

For its part, the regenerative paradigm connects with transformative tourism to restore a global post COVID-19 tourism system, based on transmodern "cultural creatives" [48] that provide and demand tourism products and services based on social and environmental values, whose journeys are a means to reinvent themselves and the world in which they live. New post COVID-19 travelers' value slow tourism, small and local (especially gastronomy), are connected, communicative and seek experiences that help them develop personally and collectively. For Ateljević [49] these new proposals are indicators of emerging global change in human consciousness and not just market segments of "special interest". That is, one must emphasize the need to travel again as a journey of purpose, with a meaning, with an adventure and as an exploration, overcoming mass tourism, a clear example that it would be an unsustainable activity in a destination [50].

The challenges that arise in the post COVID-19 world challenges challenge tourism stakeholders to develop transition plans with scenarios incorporating sustainability, resilience and internationalization [17]. Therefore, the work that arises on the role of robotics and the development of technology in the adaptations necessary to deal with the safety and hygiene measures imposed by the pandemic in airports, shopping centers, tourist accommodation or restaurants [51] is necessary. Also necessary are scientific research on adaptation to tourist cities that models and techniques based on robotics and computing, and which represent a context of particular application of resilience [52] estimating the spread of COVID-19 in meaningful urban contexts [53]. It will also be necessary to take into account the implications of the pandemic on information systems and in the proactive collection of data for knowledge of future tourist demand based on the use of Big Data and not on historical data [54].

\subsection{Security measures in tourism.}

The pandemic has paralyzed tourism globally and its relaunch at the so-called "new normal" stage requires a balance between maintaining a satisfactory experience for tourists and complying with the strict measures taken by the authorities on safety and hygiene to ensure a reactivation of the tourism industry once the containment phase has passed. Thus, the World Travel and Tourism Council (WTTC) presented in mid-May the global protocols for the revival of the tourism sector with the claim of building consumer confidence, recovering jobs and compensating for the financial losses caused by the fall in tourism worldwide. The protocols capture measures that have been designed by all industry representatives worldwide and are based on medical evidence, standards established by the World Health Organization (WHO) and the Centers for Disease Prevention (CDC). They constitute a means of approval of criteria and provide health guidance to suppliers, travel operators and tourists.

Regarding tourist accommodation, and specifically the case of hotels, these protocols and recommendations have been the subject not only at a global scale but also by the European Commission, through the communication for the progressive restart of tourism services and health 
protocols in hospitality establishments (2020/C 169/01), published in the Official Journal of the EU of 15 May 2020 [55], and of national governments, which, in the case of Spain, it has been formalized in a document prepared by the Institute for Spanish Tourism Quality [56] in coordination with the Secretary of State for Tourism, the Autonomous Communities and the EMFF. According to all of them, the measures and recommendations designed for their development and application in hotel establishments have generally been realized in: processes of deep cleaning and hand washing, between staff and customers, and use of protective equipment (masks, gloves and other protective measures); cleaning and disinfection of common spaces and contact points such as railings, tables, handles, sinks, etc.; disinfection of room cards, TV controls, light switches, and thermostats as well as the promotion of electronic payment; installation of alcohol-based hand sanitizer dispensers on each floor, in entrances and outlets; cleaning and reduced capacity in elevators; , as well as encourage the use of stairs; In-room breakfast delivery, if possible, and guarantee in buffets that guests do not handle food. They also point to the importance of assigned seating plans in common areas to avoid physical contact and agglomerations, as well as clear information and signage; limitation of capacity, social distance and identification of risk zones in entrances and points of greater influx; completion of risk assessment questionnaires before accessing the establishment; reservation of isolation spaces in the hotel itself for users presenting symptoms of COVID-19 during their stay.

In relation to the above measures, it is worth noting the study carried out in hotels in the Canary Islands [57] whose results on the changes that the pandemic has brought in tourist accommodation reveal that the protocols implemented will be sufficient for the reopening of tourism, that the greatest adaptation efforts are concentrated in the common areas, areas of restoration and cleaning of rooms. The most important measures related to common areas are social estrangement and the use of PPE by workers; while major re-opening investments focus on protective equipment and signage to organize customer transit, followed by bulkhead placement.

\subsection{Research hypothesis.}

According to the scientific literature, the hypotheses to be contrasted are as follows:

- Hypothesis 1) The level of requirements for security measures in hotel establishments is the same for women and men.

- Null hypothesis $\left(\mathrm{H}_{0}\right)$ : there is equality in terms of the level of requirement.

- Alternative hypothesis $\left(\mathrm{H}_{1}\right)$ : there are gender differences in the level of requirements.

- Hypothesis 2.1) The level of demand for respecting social distance in hotels is the same for women and men.

- Null hypothesis $\left(\mathrm{H}_{0}\right)$ : there is equality in terms of the level of requirement.

- Alternative hypothesis $\left(\mathrm{H}_{1}\right)$ : there are gender differences in the level of requirements.

- Hypothesis 2.2) The level of requirement regarding the good hygienic conditions that a hotel must present is the same for women and men.

- Null hypothesis $\left(\mathrm{H}_{0}\right)$ : there is equality in terms of the level of requirement.

- Alternative hypothesis $\left(\mathrm{H}_{1}\right)$ : there are gender differences in the level of requirements.

- Hypothesis 2.3) The level of demand for the information that hotel employees must have in front of COVID-19 is the same for women and men.

- Null hypothesis $\left(\mathrm{H}_{0}\right)$ : there is equality in terms of the level of requirement.

- Alternative hypothesis $\left(\mathrm{H}_{1}\right)$ : there are gender differences in the level of requirements.

- Hypothesis 2.4) The level of demand for avoiding physical contact with hotel employees is the same for women and men.

○ Null hypothesis $\left(\mathrm{H}_{0}\right)$ : there is equality in terms of the level of requirement. 
- Alternative hypothesis $\left(\mathrm{H}_{1}\right)$ : there are gender differences in the level of requirements.

- Hypothesis 2.5) The level of demand for using the mobile phone to register at the hotel is the same for women and men.

- Null hypothesis $\left(\mathrm{H}_{0}\right)$ : there is equality in terms of the level of requirement.

- Alternative hypothesis $\left(\mathrm{H}_{1}\right)$ : there are gender differences in the level of requirements.

- Hypothesis 2.6) The level of demand for considering the importance of hotels being "immune" is the same for women and men.

- Null hypothesis $\left(\mathrm{H}_{0}\right)$ : there is equality in terms of the level of requirement.

- Alternative hypothesis $\left(\mathrm{H}_{1}\right)$ : there are gender differences in the level of requirements.

- Hypothesis 2.7) The idea that it is better to stay in small hotels is just as important for women and men.

- Null hypothesis $\left(\mathrm{H}_{0}\right)$ : there is equality in terms of the level of requirement.

- Alternative hypothesis $\left(\mathrm{H}_{1}\right)$ : there are gender differences in the level of requirements.

- Hypothesis 2.8) The idea that the hotel should deliver a virus prevention kit is just as important for women and men.

- Null hypothesis $\left(\mathrm{H}_{0}\right)$ : there is equality in terms of the level of requirement.

- Alternative hypothesis $\left(\mathrm{H}_{1}\right)$ : there are gender differences in the level of requirements.

- Hypothesis 2.9) The idea that the use of QR codes should be extended in hotels is just as important for women and men.

$\circ \quad$ Null hypothesis $\left(\mathrm{H}_{0}\right)$ : there is equality in terms of the level of requirement.

- Alternative hypothesis $\left(\mathrm{H}_{1}\right)$ : there are gender differences in the level of requirements.

- Hypothesis 2.10) The idea that disinfectants such as ozone should be used in hotels is just as important for women and men.

- Null hypothesis $\left(\mathrm{H}_{0}\right)$ : there is equality in terms of the level of requirement.

- Alternative hypothesis $\left(\mathrm{H}_{1}\right)$ : there are gender differences in the level of requirements.

- Hypothesis 2.11) The idea that there should be health checks in hotels is just as important for women and men.

- Null hypothesis $\left(\mathrm{H}_{0}\right)$ : there is equality in terms of the level of requirement.

- Alternative hypothesis $\left(\mathrm{H}_{1}\right)$ : there are gender differences in the level of requirements.

- Hypothesis 2.12) The idea that official information should exist in hotels is just as important for women and men.

- Null hypothesis $\left(\mathrm{H}_{0}\right)$ : there is equality in terms of the level of requirement.

- Alternative hypothesis $\left(\mathrm{H}_{1}\right)$ : there are gender differences in the level of requirements.

- Hypothesis 2.13) The idea that hotels should adapt to World Health Organization (WHO) recommendations is just as important for women and men.

- Null hypothesis $\left(\mathrm{H}_{0}\right)$ : there is equality in terms of the level of requirement.

- Alternative hypothesis $\left(\mathrm{H}_{1}\right)$ : there are gender differences in the level of requirements.

- Hypothesis 2.14) The idea that hotels should have a quality certification for coronavirus prevention and control is just as important for women and men.

- Null hypothesis $\left(\mathrm{H}_{0}\right)$ : there is equality in terms of the level of requirement.

- Alternative hypothesis $\left(\mathrm{H}_{1}\right)$ : there are gender differences in the level of requirements. 
- Hypothesis 2.15) The idea that hotels should measure the temperature of customers is just as important for women and men.

- Null hypothesis $\left(\mathrm{H}_{0}\right)$ : there is equality in terms of the level of requirement.

- Alternative hypothesis $\left(\mathrm{H}_{1}\right)$ : there are gender differences in the level of requirements.

- Hypothesis 2.16) The idea that hotels should inform customers about protocols and measures is just as important for women and men.

- Null hypothesis $\left(\mathrm{H}_{0}\right)$ : there is equality in terms of the level of requirement.

- Alternative hypothesis $\left(\mathrm{H}_{1}\right)$ : there are gender differences in the level of requirements.

- Hypothesis 2.17) The idea that hotels should be eliminated physical contact between people is just as important for women and men.

- Null hypothesis $\left(\mathrm{H}_{0}\right)$ : there is equality in terms of the level of requirement.

Alternative hypothesis $\left(\mathrm{H}_{1}\right)$ : there are gender differences in the level of requirements.

\section{Methodology.}

\subsection{Data collection.}

The methodology used in this research is based on the realization of a field work to a representative sample of people in Spain to know their opinions and perceptions of what tourism will look like after the pandemic.

The data collection process was conducted through an online survey. Fieldwork was carried out between April and June 2020. This research collected a total of 332 responses, of which 328 were valid. To test the reliability of the scale, Cronbach's Alpha test was performed, yielding a value of 0.830 , a value above the minimum limits of 0.7 set by Nunnally and Bernstein [58]

\subsection{Survey questionnarie.}

The quantitative methodology used in this research has been based on a questionnaire based on previous studies [57,59-61]. The questionnaire was completely anonymous and was divided into three clearly differentiated blocks. The first block addressed questions related to the respondent's way of making the trip. The second of the blocks addressed aspects that looked at the measures taken in hotels and how this pandemic can affect the tourist experience in a given destination. The third block addressed the sociodemographic profile of respondents where aspects such as gender, age, level of study or household income were analyzed.

The questions included within the second block were asked through five-point Likert scales, where 1 referred to "Very much disagree," 3 "Neither disagree nor agree" and 5 "Very much agree". The questions included in the first and third blocks were closed.

\subsection{Data analysis.}

In order to contrast the assumptions raised (with an alpha of 0.05) two statistical techniques are used: the t-test for the case of hypothesis 1 because it is only one dependent variable (safety requirement indicator) and the analysis of the variance, or ANOVA, of a single factor for the case of hypothesis 2 as they are multiple dependent variables (set of safety measures).

In both cases, it is assumed that the sample meets the necessary requirements of normality, homoscedasticity and independence $[62,63]$ which allow the use of both techniques.

Both the preliminary analysis of the data, its processing and tabulation was carried out in the statistical program SPSS V.25 executed on MAC OS Catalina. 


\section{Research results.}

\subsection{Sociodemographic profile.}

According to the data presented in Table 1, it can be concluded that the profile of the person participating in this study is that of a young woman with residencia in Andalusia (Spain) who is employed or employed, and that she has an income that can range from 1,000 to 2,500 euros.

Table 1. Socio-demographic profile.

\begin{tabular}{|c|c|c|c|c|c|}
\hline & Variable & $\%$ & & Variable & $\%$ \\
\hline \multirow{2}{*}{$\begin{array}{l}\text { Gender } \\
\mathrm{N}=266\end{array}$} & Male & $40,60 \%$ & \multirow{10}{*}{$\begin{array}{l}\text { Professional } \\
\text { activity } \\
\mathrm{N}=269\end{array}$} & Liberal professional & $7,43 \%$ \\
\hline & Female & $59,40 \%$ & & Entrepreneur & $4,46 \%$ \\
\hline \multirow{6}{*}{$\begin{array}{l}\text { Age } \\
\mathrm{N}=328\end{array}$} & Less than $20 \mathrm{y} / \mathrm{o}$ & $35,37 \%$ & & Public servant & $22,68 \%$ \\
\hline & Between 20 and $29 \mathrm{y} / \mathrm{o}$ & $24,70 \%$ & & Full-time employee & $24,16 \%$ \\
\hline & Between 30 and $39 \mathrm{y} / \mathrm{o}$ & $10,67 \%$ & & Part-time employee & $4,09 \%$ \\
\hline & Between 40 and $49 \mathrm{y} / \mathrm{o}$ & $8,84 \%$ & & Self-employed & $3,72 \%$ \\
\hline & Between 50 and $59 \mathrm{y} / \mathrm{o}$ & $16,16 \%$ & & Student & $25,28 \%$ \\
\hline & More than $60 \mathrm{y} / \mathrm{o}$ & $4,27 \%$ & & Unemployed & $5,95 \%$ \\
\hline \multirow{12}{*}{$\begin{array}{l}\text { Region } \\
\mathrm{N}=262\end{array}$} & Andalusia & $66,79 \%$ & & Retired & $1,12 \%$ \\
\hline & Community of Madrid & $7,63 \%$ & & Household work & $1,12 \%$ \\
\hline & Basque Country & $4,58 \%$ & \multirow{4}{*}{$\begin{array}{l}\text { Education } \\
\text { level } \\
\mathrm{N}=268\end{array}$} & Primary/Secondary Education & $2,24 \%$ \\
\hline & Outside Spain & $4,58 \%$ & & A level & $19,40 \%$ \\
\hline & Extremadura & $3,82 \%$ & & University degree & $41,42 \%$ \\
\hline & Castilla La Mancha & $2,67 \%$ & & Postgraduate/Master's/PhD & $36,94 \%$ \\
\hline & Catalonia & $2,29 \%$ & \multirow{6}{*}{$\begin{array}{l}\text { Income } \\
(€ / \text { month }) \\
\mathrm{N}=262\end{array}$} & Less than 700 euros & $4,96 \%$ \\
\hline & Asturias & $1,91 \%$ & & From 700 to 1,000 euros & $11,83 \%$ \\
\hline & Canary Islands & $1,53 \%$ & & From 1,001 to 1,500 euros & $24,81 \%$ \\
\hline & Castilla y Leon & $1,15 \%$ & & From 1,501 to 2,500 euros & $25,19 \%$ \\
\hline & Community of Valencia & $1,15 \%$ & & From 2,500 to 3,500 euros & $16,41 \%$ \\
\hline & Others & $1,91 \%$ & & More than 3,500 euros & $16,79 \%$ \\
\hline
\end{tabular}

\subsection{Descriptive analysis.}

From each of the defined security measures, what has been called a safety requirement indicator (Table 2) has been developed, which can measure the overall level of requirement for the security measures demanded and with which hypothesis 1 can be contrasted.

Table 2. Security measures and indicator

\begin{tabular}{lll}
\hline & \multicolumn{1}{c}{ Measures } & Indicator \\
\hline SM1 & In the hotel you must respect the social distance. & \\
SM2 & The hotel must have good hygienic conditions. & \\
SM3 & Employees are well trained in against COVID-19. & \\
SM4 & Physical contact with employees should be avoided. & Safety \\
SM5 & You must use your mobile phone to check into the hotel. & requirement \\
SM6 & It's important that hotels are "immune". & indicator (SRI) \\
SM7 & It's better to stay in small hotels. & \\
SM8 & The hotel must deliver a virus prevention kit. & \\
SM9 & In hotels the use of QR codes should be encouraged. & \\
SM10 & Disinfectants such as ozone should be used in hotels. & \\
SM11 & There must be health checks. & \\
SM12 & There must be official information. & \\
SM13 & It must be adapted to the recommendations of the World Health &
\end{tabular}




$$
\begin{aligned}
& \text { SM14 } \begin{array}{l}
\text { Must have a quality certification for COVID-19 prevention and } \\
\text { control. }
\end{array} \\
& \text { SM15 Customers' temperature must be measured. } \\
& \text { SM16 Customers should be informed about protocols and measures. } \\
& \text { SM17 Physical contact between people must be eliminated. }
\end{aligned}
$$

Source: own elaboration

Table 3 lists, disaggregated by sex, the main descriptive statistics of the indicator of the security requirement. For this indicator, women are found to have an average value higher than men.

Table 3. Descriptive statistics

\begin{tabular}{ccccccccccc}
\hline & \multicolumn{1}{c}{ Men } & \multicolumn{1}{c}{ Women } \\
\cline { 2 - 13 } & $\mathrm{N}$ & Av & SD & As & Ct & N & Av. & SD & As & Ct. \\
IES & 104 & 4,500 & 0,5912 & $-0,719$ & $-0,436$ & 156 & 4,744 & 0,4666 & $-1,506$ & 1,186 \\
\hline
\end{tabular}

Notes: Average (Av), Standard deviation (SD), Asymmetry (As), Curtosis (Ct).

Source: own elaboration

On the other hand, table 4 shows the main descriptive statistics for each of the security measures (SM) identified in this investigation.

A first assessment makes it possible to verify that all safety measures, except SM7, obtain a valuation average of more than 3.5. In the case of the SM7, a measure that assesses the possibility of

\begin{tabular}{|c|c|c|c|c|c|c|c|c|c|c|c|c|}
\hline \multirow{2}{*}{ Variable } & \multicolumn{6}{|c|}{ Men } & \multicolumn{6}{|c|}{ Women } \\
\hline & $\mathrm{N}$ & Av & SD & As & $\mathrm{Ct}$ & $\mathrm{Rk}$ & $\mathrm{N}$ & Av & SD & As & $\mathrm{Ct}$ & $\mathrm{Rk}$ \\
\hline SM1 & 109 & 4,459 & 0,776 & $-1,252$ & 0,661 & 3 & 158 & 4,690 & 0,574 & $-1,705$ & 1,896 & 4 \\
\hline SM2 & 109 & 4,862 & 0,499 & $-5,270$ & 34,617 & 1 & 158 & 4,981 & 0,137 & $-7,117$ & 49,269 & 1 \\
\hline SM3 & 109 & 4,395 & 0,933 & $-1,846$ & 3,518 & 5 & 158 & 4,627 & 0,753 & $-1,892$ & 2,436 & 6 \\
\hline SM4 & 109 & 4,202 & 0,911 & $-1,088$ & 0,819 & 7 & 158 & 4,475 & 0,879 & $-1,943$ & 3,867 & 8 \\
\hline SM5 & 109 & 3,881 & 1,238 & $-0,874$ & $-0,245$ & 12 & 157 & 4,000 & 1,155 & $-0,886$ & $-0,076$ & 14 \\
\hline SM6 & 107 & 4,084 & 1,158 & $-1,131$ & 0,409 & 9 & 158 & 4,411 & 0,945 & $-1,735$ & 2,595 & 10 \\
\hline SM7 & 109 & 2,817 & 1,172 & 0,154 & $-0,484$ & 17 & 157 & 2,975 & 1,245 & 0,089 & $-0,721$ & 17 \\
\hline SM8 & 108 & 3,565 & 1,210 & $-0,558$ & $-0,451$ & 15 & 158 & 3,772 & 1,246 & $-0,738$ & $-0,397$ & 16 \\
\hline SM9 & 109 & 3,917 & 1,123 & $-0,713$ & $-0,428$ & 11 & 157 & 4,089 & 1,094 & $-1,101$ & 0,541 & 12 \\
\hline SM10 & 109 & 3,670 & 1,210 & $-0,551$ & $-0,561$ & 13 & 158 & 4,095 & 1,199 & $-1,219$ & 0,565 & 11 \\
\hline SM11 & 108 & 4,194 & 0,981 & $-1,189$ & 0,965 & 8 & 158 & 4,437 & 0,913 & $-1,794$ & 3,029 & 9 \\
\hline SM12 & 109 & 4,404 & 0,992 & $-2,106$ & 4,410 & 4 & 158 & 4,684 & 0,629 & $-2,432$ & 7,748 & 5 \\
\hline SM13 & 109 & 4,587 & 0,735 & $-2,015$ & 3,932 & 2 & 158 & 4,829 & 0,440 & $-2,624$ & 6,458 & 2 \\
\hline SM14 & 109 & 4,073 & 1,069 & $-1,168$ & 0,846 & 10 & 158 & 4,544 & 0,834 & $-2,178$ & 5,182 & 7 \\
\hline SM15 & 109 & 3,661 & 1,256 & $-0,643$ & $-0,538$ & 14 & 158 & 4,089 & 1,186 & $-1,195$ & 0,507 & 13 \\
\hline SM16 & 108 & 4,278 & 0,874 & $-1,348$ & 2,215 & 6 & 158 & 4,709 & 0,611 & $-1,949$ & 2,489 & 3 \\
\hline SM17 & 109 & 3,523 & 1,237 & $-0,398$ & $-0,882$ & 16 & 158 & 3,994 & 1,159 & $-0,882$ & $-0,195$ & 15 \\
\hline
\end{tabular}
considering small hotel accommodation as safer, it obtains, in both men and women, the lowest of the average ratings, even less than 3.

Table 4. Descriptive statistics (Classification of measures by gender)

Notes: Average (Av), Standard deviation (SD), Asymmetry (As), Curtosis (Ct), Ranking (Rk)

Source: own elaboration

Table 4 also lists the classification, according to the average assessment, of the safety measures that are considered most important according to sex. In each and every security measure, women have made higher assessments than men. If applicable, the first seven security measures they value score above 4.5. For their part, men only place two safety measures with scores above 4.5. 


\subsection{Analysis of differences and hypothesis contrast.}

To check whether the difference in means that exists in relation to the assessment of the safety requirement indicator (SRI) carried out by men and women is significant, the t-test is used. Table 6, which shows the results of that test, shows that there is a significant difference, with a $95 \%$ confidence interval, between the indicator averages.

Therefore, regarding hypothesis 1, the null hypothesis is rejected, and the alternative hypothesis is accepted, stating that there are differences in the means, in other words, women are more stringent in terms of the measures to be taken in hotel establishments.

Table 6. T-test for hypothesis 1

\begin{tabular}{|c|c|c|c|c|c|c|c|c|c|c|}
\hline & & Leven & e test & & & & st for averag & equality & & \\
\hline & & $\mathrm{F}$ & Sig. & $t$ & Df & $\begin{array}{c}\text { Sig. } \\
\text { (bilateral) }\end{array}$ & $\begin{array}{l}\text { Averages } \\
\text { difference }\end{array}$ & $\begin{array}{l}\text { Standard } \\
\text { error }\end{array}$ & $\begin{array}{r}95 \% \text { col } \\
\text { interva } \\
\text { diffe }\end{array}$ & $\begin{array}{l}\text { fidence } \\
1 \text { of the } \\
\text { rence }\end{array}$ \\
\hline & & & & & & & & & Lower & Superior \\
\hline & $\begin{array}{l}\text { Equal variances are } \\
\text { assumed }\end{array}$ & 27,481 & 0,000 & $-3,701$ & 258 & 0,000 & $-0,24359$ & 0,06582 & $-0,3732$ & $-0,11398$ \\
\hline IES & $\begin{array}{l}\text { Non-equal } \\
\text { variances are not } \\
\text { assumed }\end{array}$ & & & $-3,532$ & 185,1 & 0,001 & $-0,24359$ & 0,06897 & $-0,37965$ & $-0,10753$ \\
\hline
\end{tabular}

Source: own elaboration

Otherwise, to determine the extent to which average differences in each of the security measures are significant in terms of sex and therefore to be able to contrast hypothesis 2 , the analysis of the variance of one factor has been used. Table 7 shows the outcome of this analysis.

Table 7. Analysis of variance (ANOVA)

\begin{tabular}{|c|c|c|c|c|c|c|}
\hline \multicolumn{2}{|c|}{ Security measure } & Sum of squares & Df & Quadratic average & $\mathbf{F}$ & Sig. \\
\hline \multirow{3}{*}{ SM1 } & Between groups & 3,447 & 1 & 3,447 & & \\
\hline & Within groups & 116,868 & 265 & 0,441 & 7,815 & 0,006 \\
\hline & Total & 120,315 & 266 & & & \\
\hline \multirow{3}{*}{ SM2 } & Between groups & 0,908 & 1 & 0,908 & & \\
\hline & Within groups & 29,879 & 265 & 0,113 & 8,051 & 0,005 \\
\hline & Total & 30,787 & 266 & & & \\
\hline \multirow{3}{*}{ SM3 } & Between groups & 3,474 & 1 & 3,474 & & \\
\hline & Within groups & 183,005 & 265 & 0,691 & 5,031 & 0,026 \\
\hline & Total & 186,479 & 266 & & & \\
\hline \multirow{3}{*}{ SM4 } & Between groups & 4,802 & 1 & 4,802 & & \\
\hline & Within groups & 210,958 & 265 & 0,796 & 6,032 & 0,015 \\
\hline & Total & 215,760 & 266 & & & \\
\hline \multirow{3}{*}{ SM5 } & Between groups & 0,915 & 1 & 0,915 & & \\
\hline & Within groups & 373,450 & 264 & 1,415 & 0,647 & 0,422 \\
\hline & Total & 374,365 & 265 & & & \\
\hline \multirow{3}{*}{ SM6 } & Between groups & 6,833 & 1 & 6,833 & & \\
\hline & Within groups & 282,502 & 263 & 1,074 & 6,362 & 0,012 \\
\hline & Total & 289,336 & 264 & & & \\
\hline \multirow{3}{*}{ SM7 } & Between groups & 1,606 & 1 & 1,606 & & \\
\hline & Within groups & 390,228 & 264 & 1,478 & 1,087 & 0,298 \\
\hline & Total & 391,835 & 265 & & & \\
\hline \multirow{3}{*}{ SM8 } & Between groups & 2,758 & 1 & 2,758 & & \\
\hline & Within groups & 400,344 & 264 & 1,516 & 1,819 & 0,179 \\
\hline & Total & 403,102 & 265 & & & \\
\hline
\end{tabular}




\begin{tabular}{|c|c|c|c|c|c|c|}
\hline \multirow{3}{*}{ SM9 } & Between groups & 1,898 & 1 & 1,898 & & \\
\hline & Within groups & 323,008 & 264 & 1,224 & 1,551 & 0,214 \\
\hline & Total & 324,906 & 265 & & & \\
\hline \multirow{3}{*}{ SM10 } & Between groups & 11,662 & 1 & 11,662 & & \\
\hline & Within groups & 383,686 & 265 & 1,448 & 8,055 & 0,005 \\
\hline & Total & 395,348 & 266 & & & \\
\hline \multirow{3}{*}{ SM11 } & Between groups & 3,765 & 1 & 3,765 & & \\
\hline & Within groups & 233,784 & 264 & 0,886 & 4,252 & 0,04 \\
\hline & Total & 237,549 & 265 & & & \\
\hline \multirow{3}{*}{ SM12 } & Between groups & 5,052 & 1 & 5,052 & & \\
\hline & Within groups & 168,416 & 265 & 0,636 & 7,95 & 0,005 \\
\hline & Total & 173,468 & 266 & & & \\
\hline \multirow{3}{*}{ SM13 } & Between groups & 3,776 & 1 & 3,776 & & \\
\hline & Within groups & 88,808 & 265 & 0,335 & 11,268 & 0,001 \\
\hline & Total & 92,584 & 266 & & & \\
\hline \multirow{3}{*}{ SM14 } & Between groups & 14,304 & 1 & 14,304 & & \\
\hline & Within groups & 232,603 & 265 & 0,878 & 16,296 & 0,000 \\
\hline & Total & 246,906 & 266 & & & \\
\hline \multirow{3}{*}{ SM15 } & Between groups & 11,819 & 1 & 11,819 & & \\
\hline & Within groups & 391,2 & 265 & 1,476 & 8,006 & 0,005 \\
\hline & Total & 403,019 & 266 & & & \\
\hline \multirow{3}{*}{ SM16 } & Between groups & 11,921 & 1 & 11,921 & & \\
\hline & Within groups & 140,274 & 264 & 0,531 & 22,436 & 0,000 \\
\hline & Total & 152,195 & 265 & & & \\
\hline \multirow{3}{*}{ SM17 } & Between groups & 14,293 & 1 & 14,293 & & \\
\hline & Within groups & 376,186 & 265 & 1,42 & 10,069 & 0,002 \\
\hline & Total & 390,479 & 266 & & & \\
\hline
\end{tabular}

Source: own elaboration

The results achieved show that the set of hypotheses presented in Table 8 is contrast with a confidence level of $95 \%$.

Tabla 8. Hipótesis aceptadas y rechazadas.

\begin{tabular}{|c|c|c|}
\hline & Hypothesis & Accepted or rejected \\
\hline \multirow{2}{*}{ Hypothesis 2.1) } & Null Hypothesis $\left(\mathrm{H}_{0}\right)$ & Rejected \\
\hline & Alternative hypothesis $\left(\mathrm{H}_{1}\right)$ & Accepted \\
\hline \multirow{2}{*}{ Hypothesis 2.2) } & Null Hypothesis $\left(\mathrm{H}_{0}\right)$ & Rejected \\
\hline & Alternative hypothesis $\left(\mathrm{H}_{1}\right)$ & Accepted \\
\hline \multirow{2}{*}{ Hypothesis 2.3) } & Null Hypothesis $\left(\mathrm{H}_{0}\right)$ & Rejected \\
\hline & Alternative hypothesis $\left(\mathrm{H}_{1}\right)$ & Accepted \\
\hline \multirow{2}{*}{ Hypothesis 2.4) } & Null Hypothesis $\left(\mathrm{H}_{0}\right)$ & Rejected \\
\hline & Alternative hypothesis $\left(\mathrm{H}_{1}\right)$ & Accepted \\
\hline \multirow{2}{*}{ Hypothesis 2.5) } & Null Hypothesis $\left(\mathrm{H}_{0}\right)$ & Accepted \\
\hline & Alternative hypothesis $\left(\mathrm{H}_{1}\right)$ & Rejected \\
\hline \multirow{2}{*}{ Hypothesis 2.6) } & Null Hypothesis $\left(\mathrm{H}_{0}\right)$ & Rejected \\
\hline & Alternative hypothesis $\left(\mathrm{H}_{1}\right)$ & Accepted \\
\hline \multirow{2}{*}{ Hypothesis 2.7) } & Null Hypothesis $\left(\mathrm{H}_{0}\right)$ & Accepted \\
\hline & Alternative hypothesis $\left(\mathrm{H}_{1}\right)$ & Rejected \\
\hline \multirow{2}{*}{ Hypothesis 2.8) } & Null Hypothesis $\left(\mathrm{H}_{0}\right)$ & Accepted \\
\hline & Alternative hypothesis $\left(\mathrm{H}_{1}\right)$ & Rejected \\
\hline \multirow{2}{*}{ Hypothesis 2.9) } & Null Hypothesis $\left(\mathrm{H}_{0}\right)$ & Accepted \\
\hline & Alternative hypothesis $\left(\mathrm{H}_{1}\right)$ & Rejected \\
\hline \multirow{2}{*}{ Hypothesis 2.10) } & Null Hypothesis $\left(\mathrm{H}_{0}\right)$ & Rejected \\
\hline & Alternative hypothesis $\left(\mathrm{H}_{1}\right)$ & Accepted \\
\hline \multirow{2}{*}{ Hypothesis 2.11) } & Null Hypothesis $\left(\mathrm{H}_{0}\right)$ & Rejected \\
\hline & Alternative hypothesis $\left(\mathrm{H}_{1}\right)$ & Accepted \\
\hline Hypothesis 2.12) & Null Hypothesis $\left(\mathrm{H}_{0}\right)$ & Rejected \\
\hline
\end{tabular}




\begin{tabular}{lll} 
& Alternative hypothesis $\left(\mathrm{H}_{1}\right)$ & Accepted \\
Hypothesis 2.13) & Null Hypothesis $\left(\mathrm{H}_{0}\right)$ & Rejected \\
& Alternative hypothesis $\left(\mathrm{H}_{1}\right)$ & Accepted \\
Hypothesis 2.14) & Null Hypothesis $\left(\mathrm{H}_{0}\right)$ & Rejected \\
& Alternative hypothesis $\left(\mathrm{H}_{1}\right)$ & Accepted \\
Hypothesis 2.15) & Null Hypothesis $\left(\mathrm{H}_{0}\right)$ & Rejected \\
& Alternative hypothesis $\left(\mathrm{H}_{1}\right)$ & Accepted \\
Hypothesis 2.16) & Null Hypothesis $\left(\mathrm{H}_{0}\right)$ & Rejected \\
& Alternative hypothesis $\left(\mathrm{H}_{1}\right)$ & Accepted \\
Hypothesis 2.17) & Null Hypothesis $\left(\mathrm{H}_{0}\right)$ & Rejected \\
& Alternative hypothesis $\left(\mathrm{H}_{1}\right)$ & Accepted \\
\hline
\end{tabular}

It can therefore be said that women, in addition to being more demanding than men in terms of the safety measures to be taken in hotel establishments in relation to 19, are also more demanding in terms of different measures such as: good hygiene conditions, the use of disinfectants such as ozone, the existence of health checks and official information, adapting the establishment to WHO recommendations, obtaining quality certification for coronavirus prevention and control, measuring temperature to customers, as well as the need to provide information to customers on protocols and measures and, finally, elimination of physical contact between people.

COVID-19 pandemic has been taking place in 2020, involving radical changes in people's behavior. In fact, one of the main sectors affected has been tourism activity, and especially hotel establishments. these establishments have had to adapt to respond to this pandemic. As a result, hotel establishments have strengthened their hygienic conditions.

This article presents the results of research conducted in Spain to learn how COVID-19 will affect the perceptions and experiences of post COVID-19 tourists.

To analyze these results, it has been segmented by gender. The main results of this research support that women are much more demanding in terms of the sanitary conditions that require hotel establishments to consider them safer, in such aspects, such as the need to make a greater disinfection of the rooms and public spaces of the hotel establishment.

\section{Conclusions.}

COVID-19 pandemic has been taking place in 2020, involving radical changes in people's behavior. In fact, one of the main sectors affected has been tourism activity, and especially hotel establishments. these establishments have had to adapt to respond to this pandemic. As a result, hotel establishments have strengthened their hygienic conditions.

This article presents the results of research conducted in Spain to learn how COVID-19 will affect the perceptions and experiences of post-COVID-19 tourists.

To analyze these results, it has been segmented by gender. The main results of this research support that women are much more demanding in terms of the sanitary conditions that require hotel establishments to consider them safer, in such aspects, such as the need to make a greater disinfection of the rooms and public spaces of the hotel establishment.

The main practical application of this research is that hotel establishments have results that allow it to offer better conditions to their customers, thus reinforcing their image. As for the limitations of this investigation, we could consider two. The first limitation is that the field work was carried out in April and June 2020, that is, during the first wave of COVID-19. The second limitation is that it was only made to demand and not to supply.

As a future line of research, a study is proposed to hotel establishments to analyze what kind of measures they are taking in the face of this pandemic. 
Author Contributions: Conceptualization, A.L.E., R.R.L., T.L-F. and A.M.C.; methodology, A.L.E. and R.R.L.; software, A.L.E. and R.R.L.; formal analysis, A.L.E. and R.R.L.; investigation, A.L.E., R.R.L. and T.L-F.; resources, A.M.C.; writing-original draft preparation, A.L.E., R.R.L. and T.L-F.; writing-review and editing, A.L.E., R.R.L. and T.L-F; supervision, R.R.L..; project administration, R.R.L..

Funding: This research received no external funding.

Conflicts of Interest: The authors declare no conflict of interest.

\section{References}

1. Yang, Y.; Zhang, H.; Chen, X. Coronavirus pandemic and tourism: Dynamic stochastic general equilibrium modeling of infectious disease outbreak. Annals of tourism research 2020, 10.1016/j.annals.2020.102913, 102913-102913, doi:10.1016/j.annals.2020.102913.

2. Jamal, T.; Budke, C. Tourism in a world with pandemics: local-global responsibility and action. Journal of Tourism Futures 2020, 10.1108/JTF-02-2020-0014, doi:10.1108/JTF-02-2020-0014.

3. Hoque, A.; Shikha, F.A.; Hasanat, M.W.; Arif, I.; Hamid, A.B.A. The effect of Coronavirus (COVID-19) in the tourism industry in China. Asian Journal of Multidisciplinary Studies 2020, 3, 52-58.

4. Buheji, M.; Ahmed, D. Foresight of Coronavirus (COVID-19) opportunities for a better world. American Journal of Economics 2020, 10, 97-108, doi:10.5923/j.economics. 20201002.05.

5. Filimonau, V.; De Coteau, D. Tourism resilience in the context of integrated destination and disaster management (DM2). International Journal of Tourism Research 2020, 22, 202-222.

6. Del Valle, A.S. The Tourism Industry and the Impact of Covid-19, Scenarios and Proposals. Global Journey Consulting Madrid, 2020.

7. World Travel Tourism Council. Travel \& Tourism. Economic Impact 2016; World Travel \& Tourism Council (WTTC): London, 2016; p 16.

8. Hall, C.M.; Scott, D.; Gössling, S. Pandemics, transformations and tourism: be careful what you wish for. Tour. Geogr. 2020, 10.1080/14616688.2020.1759131, 1-22, doi:10.1080/14616688.2020.1759131.

9. Gössling, S.; Scott, D.; Hall, C.M. Pandemics, tourism and global change: a rapid assessment of COVID-19. Journal of Sustainable Tourism 2020, 10.1080/09669582.2020.1758708, 1-20, doi:10.1080/09669582.2020.1758708.

10. Morakabati, Y. A question of confidence. Is tourism as vulnerable to civil unrest as we think? A comparative analysis of the impact of Arab Spring on total reserves and tourism receipts. International Journal of Tourism Research 2020, 22, 252-265, doi:10.1002/jtr.2333.

11. Pennington-Gray, L. How Will Covid-19 Affect Future Travel Behavior? A Travel Crisis Expert Explains. Availabe online: https://tinyurl.com/wcogbeh (accessed on August 3, 2020).

12. Chung, L.H. Impact of pandemic control over airport economics: Reconciling public health with airport business through a streamlined approach in pandemic control. Journal of Air Transport Management 2015, 44, 42-53, doi:10.1016/j.jairtraman.2015.02.003.

13. Shaw, R.; Kim, Y.-k.; Hua, J. Governance, technology and citizen behavior in pandemic: Lessons from COVID-19 in East Asia. Progress in disaster science 2020, 10.1016/j.pdisas.2020.100090, 100090, doi:10.1016/j.pdisas.2020.100090.

14. Sohrabi, C.; Alsafi, Z.; O’Neill, N.; Khan, M.; Kerwan, A.; Al-Jabir, A.; Iosifidis, C.; Agha, R. World Health Organization declares global emergency: A review of the 2019 novel coronavirus (COVID-19). International Journal of Surgery 2020, 10.1016/j.ijsu.2020.02.034, 71-76, doi:10.1016/j.ijsu.2020.02.034. 
15. Chinazzi, M.; Davis, J.T.; Ajelli, M.; Gioannini, C.; Litvinova, M.; Merler, S.; y Piontti, A.P.; Mu, K.; Rossi, L.; Sun, K. The effect of travel restrictions on the spread of the 2019 novel coronavirus (COVID-19) outbreak. Science 2020, 368, 395-400.

16. Yang, E.C.L.; Khoo-Lattimore, C.; Arcodia, C. A systematic literature review of risk and gender research in tourism. Tourism Manage. 2017, 58, 89-100, doi:10.1016/j.tourman.2016.10.011.

17. Nientied, P.; Shutina, D. Tourism in transition, the post covid-19 aftermath in the Western Balkans. Co-PLAN Resilience Series 2020, 2, doi:10.32034/CP-PPRESI-P01-02.

18. Romagosa, F. The COVID-19 crisis: Opportunities for sustainable and proximity tourism. Tour. Geogr. 2020, 10.1080/14616688.2020.1763447, 1-5, doi:10.1080/14616688.2020.1763447.

19. World Tourism Organization. COVID-10 Tourism Recovery Technical Assistance Package; UNWTO: Madrid, 2020.

20. Brouder, P. Reset redux: possible evolutionary pathways towards the transformation of tourism in a COVID-19 world. Tour. Geogr. 2020, 10.1080/14616688.2020.1760928, 1-7, doi:10.1080/14616688.2020.1760928.

21. Suárez, S.; Fumero, E. El turismo a cero, es la hora del turismo sostenible. In Turismo pos-COVID-19, Cátedra de Turismo Caja Canarias-Ashotel de la Universidad de La Laguna, Ed. La Laguna, 2020; 10.25145/b.Turismopos-COVID-19.2020pp. 283-291.

22. Padrón, N.F.; Hernández, R.M. Reflexiones sobre sostenibilidad turística durante la pandemia: una agenda para el sector frente a los ODS. In Turismo pos-COVID-19, Universidad, C.d.T.C.-A.d.1., Ed. La Laguna, 2020; 10.25145/b.Turismopos-COVID-19.2020pp. 255-262.

23. Butler, R.W. Tourism and resilience; CABI: Wallingford, 2017.

24. Cheer, J.M.; Lew, A.A. Tourism, resilience and sustainability: Adapting to social, political and economic change; Routledge: Abingdon, 2017.

25. Hall, C.M.; Prayag, G.; Amore, A. Tourism and resilience: Individual, organisational and destination perspectives; Channel View Publications: Bristol, 2017.

26. Berbés-Blázquez, M.; Scott, D. The development of resilience thinking. Tourism and Resilience, CABI, Wallingford, Oxfordshire, UK 2017, 9-22.

27. Biggs, R.; Schlüter, M.; Schoon, M.L. Principles for building resilience: sustaining ecosystem services in social-ecological systems; Cambridge University Press: 2015.

28. Higgins-Desbiolles, F. The end of global travel as we know it: an opportunity for sustainable tourism. The Conversation 2020, 17.

29. Higgins-Desbiolles, F.; Carnicelli, S.; Krolikowski, C.; Wijesinghe, G.; Boluk, K. Degrowing tourism: rethinking tourism. Journal of Sustainable Tourism 2019, 27, 1926-1944, doi:10.1080/ 09669582.2019.1601732.

30. Navarro Jurado, E.; Ortega Palomo, G.n.; Torres Bernier, E. Propuestas de reflexion desde el turismo frente al COVID-19. Incertidumbre, impacto y recuperacion. Instituto Universitario de Investigación de Inteligencia e Innovación Turística de la Universidad de Málaga: Málaga, 2020.

31. Diaz-Soria, I. Being a tourist as a chosen experience in a proximity destination. Tour. Geogr. 2017, 19, 96-117, doi:10.1080/14616688.2016.1214976.

32. Jeuring, J.H.G.; Haartsen, T. The challenge of proximity: the (un) attractiveness of near-home tourism destinations. Tour. Geogr. 2017, 19, 118-141, doi:10.1080/14616688.2016. 1175024.

33. Lew, A. How to Create a Better Post-COVID-19 World. Availabe online: https://tinyurl.com/y6c8lga7 (accessed on August 3, 2020). 
34. Cheer, J.M. Human flourishing, tourism transformation and COVID-19: a conceptual touchstone. Tour. Geogr. 2020, 10.1080/14616688.2020.1765016, 1-11, doi:10.1080/14616688.2020.1765016.

35. Gössling, S.; Hanna, P.; Higham, J.; Cohen, S.; Hopkins, D. Can we fly less? Evaluating the 'necessity' of air travel. Journal of Air Transport Management 2019, 81, 101722, doi:/10. 1016/j.jairtraman.2019.101722.

36. Hall, C.M. Constructing sustainable tourism development: The 2030 agenda and the managerial ecology of sustainable tourism. Journal of Sustainable Tourism 2019, 27, 1044-1060, doi:10.1080/09669582.2018.1560456.

37. Mostafanezhad, M.; Norum, R. The anthropocenic imaginary: Political ecologies of tourism in a geological epoch. Journal of Sustainable Tourism 2019, 27, 421-435, doi:10. 1080/09669582.2018.1544252.

38. Vargas-Sánchez, A.; Moutinho, L. New strategic developments in tourism. Strategic Management in Tourism 2018, 332-349.

39. Reisinger, Y. Transformational tourism: Tourist perspectives; CABI: Wallingford, 2013.

40. Reisinger, Y. Transformational tourism: Host perspectives; CABI: Wallingford, 2015.

41. Lean, G.; Staiff, R.; Waterton, E. Travel and Transformation (Current Developments in the Geographies of Leisure and Tourism); Ashgate Publishing Group: Sydney, 2014.

42. Lean, G. Transformative travel in a mobile world; CABI: Sydney, 2015.

43. World Travel \& Tourism Council. Crisis Readiness, Are You Prepared and Resilient to Safeguard Your People E Destinations?; World Travel \& Tourism Council,: London, 2019.

44. Kirillova, K.; Lehto, X.Y.; Cai, L. Existential authenticity and anxiety as outcomes: The tourist in the experience economy. International Journal of Tourism Research 2017, 19, 13-26.

45. Kirillova, K.; Lehto, X.; Cai, L. What triggers transformative tourism experiences? Tourism Recreation Research 2017, 42, 498-511.

46. Soulard, J.; McGehee, N.G.; Stern, M. Transformative tourism organizations and glocalization. Annals of Tourism Research 2019, 76, 91-104.

47. Pollock, A. Flourishing beyond sustainability. The promise of a regenerative tourism. In Proceedings of ETC Workshop, Krakow.

48. Ateljević, I.; Sheldon, P.; Tomljenović, R. The new paradigm of the 21st century,'Silent revolution' of Cultural Creatives and Transformative Tourism of and for the Future. Global Report on the Transformative Power of Tourism a paradigm shift towards a more responsible traveller 2016, 12-20.

49. Ateljević, I. Transforming the (tourism) world for good and (re) generating the potential 'new normal'. Tour. Geogr. 2020, 10.1080/14616688.2020.1759134, 1-9, doi:10.1080/14616688.2020.1759134.

50. Kumar, S. Resilience, patience, equanimity \& solidarity. Availabe online: https://tinyurl.com/y5dlnfzh (accessed on August 3, 2020).

51. Zeng, Z.; Chen, P.-J.; Lew, A.A. From high-touch to high-tech: COVID-19 drives robotics adoption. Tour. Geogr. 2020, 10.1080/14616688.2020.1762118, 1-11, doi:10.1080/14616688.2020.1762118.

52. Galvani, A.; Lew, A.A.; Perez, M.S. COVID-19 is expanding global consciousness and the sustainability of travel and tourism. Tour. Geogr. 2020, 10.1080/14616688.2020.1760924, 1-10, doi:10.1080/14616688.2020.1760924.

53. D'Orazio, M.; Bernardini, G.; Quagliarini, E. Sustainable and resilient strategies for touristic cities against COVID-19: an agent-based approach. arXiv preprint arXiv:2005.12547 2020.

54. Gallego, I.; Font, X. Changes in air passenger demand as a result of the COVID-19 crisis: using Big Data to inform tourism policy. Journal of Sustainable Tourism 2020, 10.1080/09669582.2020.1773476 1-20, doi:10.1080/09669582.2020.1773476 
55. European Commission. EU Guidance for the progressive resumption of tourism services and for health protocols in hospitality establishments - COVID-19, (2020/C 169/01). In Official Journal of the European Union, 2020.

56. Instituto para la Calidad Turística de España. Medidas para la reducción del contagio por el coronavirus SARS-COV-2. Ministerio de Industria, Comercio y Turismo: Madrid, 2020.

57. González Cruz, J.P. Los hoteles ante la nueva normalidad turística: Reflexiones para el aprendizaje. In Turismo pos-COVID-19: Reflexiones, retos y oportunidades, Simancas, M., Hernández, R., Padrón, N., Eds. Cátedra de Turismo CajaCanarias-Ashotel de la Universidad de La Laguna: La Laguna, 2020; pp. 417-426.

58. Nunnally, J.; Bernstein, I. Psychometric Theory; McGraw-Hill: New York, NY, USA,, 1994.

59. Observatorio Nacional de Turismo. Informe Verano 2020. Hábitos y comportamiento del turista nacional; Observatorio Nacional de Turismo: Madrid, 2020.

60. DNA Turismo y Ocio. La Industria Turística y el COVID 19. En busca de escenarios y recetas para las nuevas fases que definirán una nueva era del turismo. DNA Turismo y Ocio,: Madrid, 2020.

61. DNA Turismo y Ocio. La Industria Turística y el COVID 19. Segunda investigación: “la opinión de la demanda": Intención de compra de productos y servicios turísticos. Nuevos hábitos de consumo turístico. DNA Turismo y Ocio,: Madrid, 2020.

62. Tejedor Tejedor, F. Aplicaciones diversas del análisis de varianza. Madrid: Editorial La Muralla, SA 2003.

63. De Winter, J.C.F. Using the Student's t-test with extremely small sample sizes. Practical Assessment, Research, and Evaluation 2013, 18, 10, doi:10.7275/e4r6-dj05.

(C) 2020 by the authors. Submitted for possible open access publication under the terms and conditions of the Creative Commons Attribution (CC BY) license (http://creativecommons.org/licenses/by/4.0/). 